\title{
Gram per Cage
}

National Cancer Institute

\section{Source}

National Cancer Institute. Gram per Cage. NCI Thesaurus. Code C73716.

A dose calculation unit expressed in gram(s) per cage. 